\title{
Iron deficiency in sickle cell anaemia
}

\author{
SALLY DAVIES, ${ }^{*}$ JOAN HENTHORN, MILICA BROZOVIĆ \\ From the Department of Haematology, Central Middlesex Hospital, London NW10 7NS
}

SUMMARY Thirty-seven patients with SCD were studied: 24 were diagnosed as homozygous Hb S on the basis of their haematological findings, and $\alpha$ :non- $\alpha$ globin chain ratios were found to be balanced in all. Thirteen patients were thought to have $\alpha$ or $\beta$ thalassaemia interaction with $\mathrm{Hb} \mathrm{S}$ on the basis of low MCV and $\mathrm{MCH}$, family history and/or presence of $\mathrm{Hb} \mathrm{A}$ on electrophoresis. Six of them had abnormal $\alpha$ :non- $\alpha$ ratio (one had a ratio of 0.72 suggestive of $\alpha$ thalassaemia, and five had ratios between 1.4 and 1.9 , compatible with $\beta$ thalassaemia interaction). The remaining seven patients with microcytosis had balanced globin chain synthesis and five were found to be iron deficient. Five additional patients ( 3 with $\mathrm{Hb}$ SS and 2 with $\mathrm{Hb} \mathrm{S} / \beta$ thalasseamia) had lower than normal serum ferritin concentration. The analysis of case histories disclosed that peptic ulceration, recurrent epistaxis and multiple pregnancies could account for iron loss in seven patients. These findings indicate that iron deficiency may be common in SCD and should be excluded as a cause of microcytosis.

Microcytosis, in the absence of conclusive family studies and/or presence of $\mathrm{Hb} \mathrm{A}$ on electrophoresis, is an unreliable indicator of $\alpha$ or $\beta$ thalassaemia interaction with $\mathrm{Hb} \mathrm{S}$.

It is always assumed that individuals with inherited severe haemolytic anaemia have iron overload due to increased iron absorption' from the gut and to repeated transfusions of blood. Iron deficiency is considered unlikely, and in sickle cell disease (SCD) microcytosis, defined by low MCV and $\mathrm{MCH}$ is taken to indicate the presence of an interaction with $\alpha$ or $\beta$ thalassaemia. Recent studies ${ }^{2-4}$ have confirmed this view by showing that individuals homozygous or heterozygous for $\alpha$ thalassaemia and $\mathrm{Hb}$ S have significantly lower MCV and $\mathrm{MCH}$ than those with a normal $\alpha$ gene complement. The presence of microcytosis in patients with $\mathrm{Hb} \mathrm{S} / \alpha$ or $\beta$ thalassaemia is well documented. ${ }^{5}$

The published data on iron status in SCD tends to confirm that excess iron is present: high serum ferritin concentration is commonly found, ${ }^{6-8}$ even in patients whose bone marrow iron stores are absent. ${ }^{7}$ There are, however, reports to the contrary: $\mathrm{O}^{\prime}$ Brien $^{8}$ reported that patients with SCD do not acquire excessive iron burden during the first two decades of life, and iron deficiency in young children with sickle cell disease has been described. ${ }^{810}$ Vichinsky and colleagues ${ }^{10}$ treated six iron deficient

*Present address: Department of Haematology, School of Pathology, Middlesex Hospital Medical School, London W1

Accepted for publication 30 March 1983 children with iron; there was an increase in $\mathrm{Hb}$ and $\frac{0}{4}$ normalisation of red cell indices in all.

We have studied 37 adults with SCD, 13 of whor had low MCV and MCH and were thought to have either $\alpha$ or $\beta$ thalassaemia interaction with $\mathrm{Hb} \mathrm{S}$. We wish to report the results of studying their iron status and their globin chain synthesis.

\section{Patients and methods}

\section{PATIENTS}

Thirty-seven patients with SCD in the steady state and at least six months after the last blood transfusion were studied. No patient had any renal function impairment. There were 18 women (mean age $21 \cdot 3$, ᄋ range $12-45 \mathrm{yr}$ ) and 19 men (mean age $22 \cdot 8$, range $₹$ 13-35 yr). Thirteen patients were thought to have 의 $\mathrm{Hb} \mathrm{S} / \alpha$ or $\beta$ thalassaemia interaction on the basis of low MCV and $\mathrm{MCH}$, presence of small amounts of Hb A (9-12\%) on electrophoresis, or family studies, $\bar{N}$ or a combination of these. The details of the thirteen $\Omega$ patients are shown in the Table. The remaining $24 \mathrm{~N}$ patients were diagnosed as $\mathrm{Hb}$ SS, and their $\underset{\omega}{N}$ haematological variables are shown at the bottom of the Table.

METHODS

Values for $\mathrm{Hb}, \mathrm{MCV}$ and $\mathrm{MCH}$ were obtained using

a Coulter Model S. Hb A2 was measured using 
Details of patients studied

\begin{tabular}{|c|c|c|c|c|c|}
\hline Case & $\underset{(y r)}{\text { Sex/Age }}$ & $\begin{array}{l}H b \\
(g / d l)\end{array}$ & $\begin{array}{l}\mathrm{MCH} \\
(\mathrm{g} / l)\end{array}$ & $\underset{\%}{A 2}$ & $\begin{array}{l}F \\
\%\end{array}$ \\
\hline $\begin{array}{l}1 \\
2^{*} \\
3^{*} \\
4 \dagger \\
5 \dagger \\
6 \\
7 \\
8 \\
9 \\
10 \\
11 \\
12 \\
13 \\
14-37\end{array}$ & $\begin{array}{l}F / 19 \\
M / 20 \\
F / 45 \\
M / 21 \\
F / 26 \\
M / 21 \\
M / 22 \\
M / 25 \\
M / 14 \\
M / 25 \\
M / 18 \\
F / 24 \\
M / 19 \\
14 F, 10 M\end{array}$ & $\begin{array}{c}9 \cdot 3 \\
10.7 \\
11 \cdot 2 \\
8 \cdot 6 \\
9 \cdot 1 \\
8 \cdot 8 \\
8 \cdot 1 \\
9 \cdot 2 \\
6 \cdot 5 \\
10 \cdot 1 \\
13 \cdot 3 \\
12 \cdot 8 \\
12 \cdot 8 \\
8 \cdot 47 \\
7 \cdot 1-9.9\end{array}$ & $\begin{array}{l}22 \cdot 4 \\
23 \cdot 6 \\
23 \cdot 1 \\
23 \cdot 8 \\
25 \cdot 0 \\
20 \cdot 8 \\
25 \cdot 3 \\
24 \cdot 2 \\
26 \cdot 4 \\
26 \cdot 9 \\
26 \cdot 6 \\
24 \cdot 5 \\
22 \cdot 0 \\
29 \cdot 0 \\
24 \cdot 2-34\end{array}$ & $\begin{array}{l}2 \cdot 2 \\
2 \cdot 0 \\
4 \cdot 8 \\
5 \cdot 2 \\
1.9 \\
3 \cdot 4 \\
2 \cdot 7 \\
2 \cdot 7 \\
1.6 \\
3 \cdot 1 \\
2.5 \\
2 \cdot 5 \\
5 \cdot 7 \\
2 \cdot 28 \\
1 \cdot 0-3 \cdot 1\end{array}$ & $\begin{array}{l}10.6 \\
2.1 \\
5.7 \\
0.9 \\
1.3 \\
6 \cdot 0 \\
1.2 \\
1.4 \\
1.5 \\
4.0 \\
3.4 \\
2.0 \\
4.8 \\
6.7 \\
0.9-16.8\end{array}$ \\
\hline
\end{tabular}

*Mother and son.

†Brother and sister.

Cases 1-13 were though to have $\mathrm{Hb} \mathrm{S} /$ thalassaemia interaction; cases 14-37 to have homozygous sickle cell anaemia.

Helena Laboratories scanning equipment of cellulose acetate strip. $\mathrm{Hb} \mathrm{F}$ was measured by the method of Betke et al. " Serum iron and total iron binding capacity (TIBC) were measured according to Young and Hicks. ${ }^{12}$ Serum ferritin concentration was measured with the Becton Dickinson radioimmune assay kit, using the method of Addison et al. ${ }^{13}$ The manufacturers suggest a normal range for women of 25$250 \mu \mathrm{g} / \mathrm{l}$, and of $50-500 \mu \mathrm{g} / \mathrm{l}$ for men. Globin chain synthesis was estimated by the method of Clegg et $a l ;^{14}$ the results were expressed as $\alpha:$ non- $\alpha$ ratio. The normal range of $\alpha$ : non- $\alpha$ ratios on nine healthy laboratory controls was $0 \cdot 88-1 \cdot 16$. The error of the method, calculated from 14 duplicate measurements was \pm 0.03 .

\section{Results}

The $\alpha$ :non- $\alpha$ globin chain synthesis ratios for the 37 patients are shown in Fig. 1. Cases 14-37, previously diagnosed as $\mathrm{Hb} \mathrm{SS}$, all had $\alpha$ :non- $\alpha$ ratios between 0.84 and $1 \cdot 27$. Of the 13 patients thought to have thalassaemia/Hb $\mathrm{S}$ interaction, six had abnormal $\alpha$ :non- $\alpha$ ratios (case 1 ratio of 0.72 , and cases $3,10,11,12$ and 13 ratios of 1.4 and over), whereas the remaining seven patients (cases 2, 4, 5, $6,7,8,9$ ) had $\alpha$ :non- $\alpha$ ratios ranging from 0.84 $1 \cdot 17$.

Serum iron, TIBC and ferritin concentration are shown in Figs. 2 and 3. It is clear from these data that patients with microcytosis and balanced globin

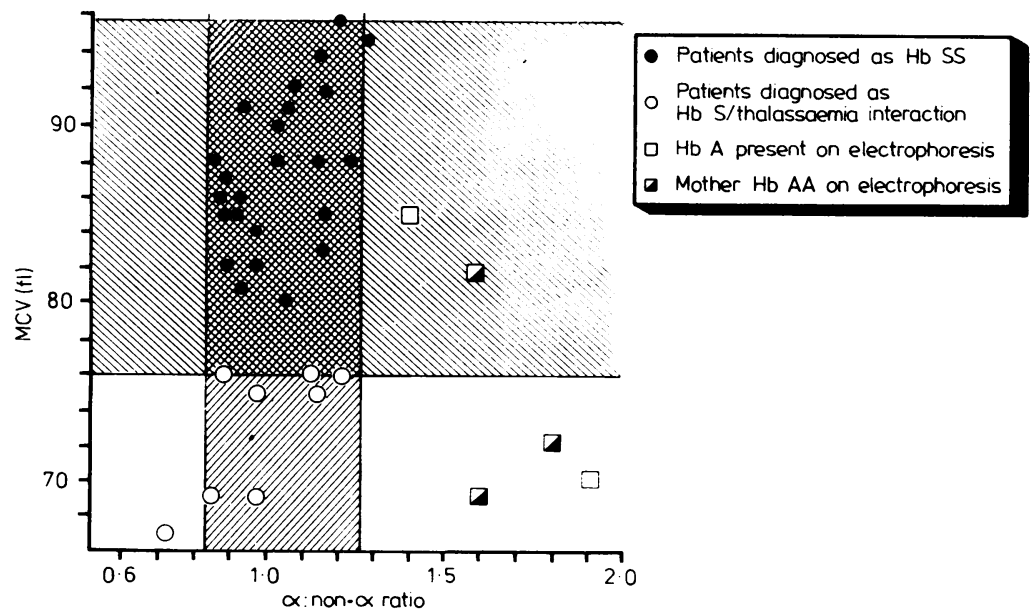

Fig. 1 The plot of MCV against $\alpha:$ non- $\alpha$ ratio in SCD. Shaded area denotes the normal range. 

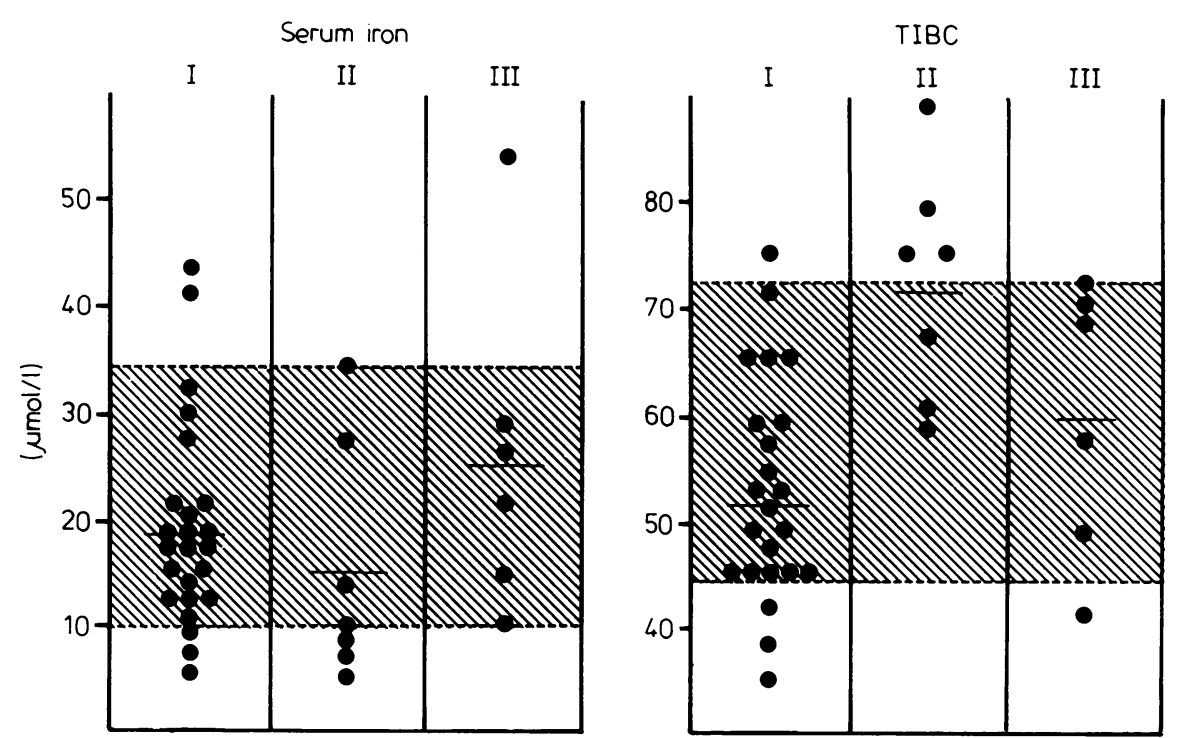

Fig. 2 Serum iron and total iron binding capacity in SCD. Group I: patients with normal MCV and balanced $\alpha: n o n-\alpha$ ratio. Group II: patients with microcytosis and normal $\alpha$ :non- $\alpha$ ratio. Group III: patients with abnormal $\alpha$ :non- $\alpha$ ratio. Horizontal lines denote normal range and mean.

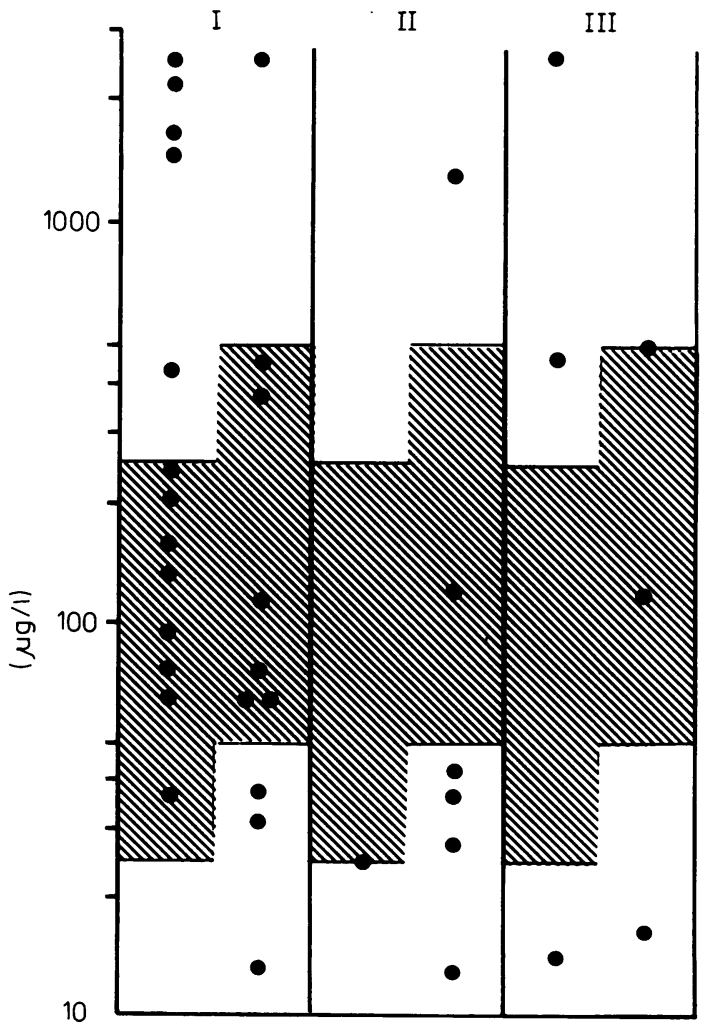

Fig. 3 Serum ferritin in SCD. Groups as for Fig. 2. Females on the left, males on the right of each column. Horizontal lines denote normal range. chain synthesis had significantly higher TIBC and lower ferritin concentration than those with normal $\stackrel{\text { - }}{\circ}$ red cell indices $(p<0.001$ for TIBC; $p<0.05 \mathrm{f} P$ $\log$ ferritin using Student's $t$ test).

Possible sources of iron loss were investigated for all patients. Five men had proven peptic ulcers, on had recurrent epistaxis and two women had multiple pregnancies without blood transfusion or iron supplementation. Of these eight patients, seven had $\underset{Q}{\mathscr{Q}}$ lower than normal serum ferritin concentration, $\stackrel{\vec{P}}{\vec{P}}$ high TIBC and microcytosis; globin chain synthesis $\frac{0}{3}$ was balanced in five. Two patients in this group, $\overrightarrow{ }$ both with balanced globin chain synthesis, required surgical treatment for peptic ulcer. Liver biopsy was carried out at operation, and stainable iron waso absent in both biopsies. Three additional patients:were iron deficient, but no source of iron loss could $\stackrel{3}{3}$ be found.

\section{Discussion}

In the absence of conclusive family history or $\mathrm{Hb} \mathrm{A}$ 垔. on electrophoresis, microcytosis is unreliable as an $N$ indicator of $\alpha$ or $\beta$ thalassaemia interaction with $\mathrm{Hb}^{\sigma}$ S. In our series, seven patients with low MCV and 0 $\mathrm{MCH}$ had balanced globin chain synthesis, and five $\underset{\omega}{\mathrm{N}}$ were found to have lower than normal serum ferritin concentration and higher TIBC.

奂

There is no evidence of increased iron load in sickle cell disease, and iron deficiency may be more $\stackrel{\oplus}{?}$ common than suspected, especially in men. The $\overparen{T}$ aetiology of iron loss is not clear, but GI tract bleed- $\frac{\vec{D}}{\bar{D}}$ 
ing due to peptic ulceration, epistaxis and multiple pregnancies can account for iron lack in seven of our patients. Iron loss in urine may also be responsible. Even in the steady state, SCD patients excrete variable but generally larger than normal amounts of iron. ${ }^{15}$ During crises, when marked intravascular sickling and haemolysis occur, the amount of iron lost in urine may be much greater.

The effect of iron deficiency on $\alpha$ :non- $\alpha$ ratio in sickle cell anaemia and sickle thalassaemia is not known. Walford and Deacon ${ }^{16}$ have shown that iron deficiency reduces the $\alpha / \beta$ chain imbalance in $\beta$ thalassaemia trait. It is thus possible that on correction of iron deficiency some of our patients may alter their $\alpha$ :non- $\alpha$ ratio and an imbalance in globin chain synthesis becomes apparent. Should this be true, one can hypothesise that individuals with $\alpha$ and $\beta$ thalassaemia/ $\mathrm{Hb} \mathrm{S}$ interaction have a propensity to develop iron deficiency, perhaps because their $\mathrm{Hb}$, PCV and RBC count are higher than in those with $\mathrm{Hb} \mathrm{SS}^{45}$ The higher count and the subsequent higher blood viscosity may be responsible for the high incidence of peptic ulceration or increased urinary iron loss. Further studies are required to elucidate these points.

We are grateful to the Department of Chemical Pathology, Central Middlesex Hospital, for carrying out serum iron and TIBC estimations; to Mr Peter Miller and $\mathrm{Mr}$ John Kennedy, Department of Haematology, Central Middlesex Hospital, for measuring serum ferritin, $\mathrm{Hb} \mathrm{F}$ and $\mathrm{Hb} \mathrm{A} 2$; and to Mrs Margaret Geary for typing the manuscript. We particularly wish to thank patients attending the Sickle Cell Clinic at the Central Middlesex Hospital for their co-operation in the study.

\section{References}

${ }^{1}$ Hoffbrand AV. Iron. In: Lewis SM, Hoffbrand AV, eds. Postgraduate haematology London: William Heinemann, 1981:65-9.
${ }^{2}$ Felice AE, Webber B, Miller B, et al. The association of sickle cell anaemia with heterozygous and homozygous $\alpha$ thalassaemia: in vitro $\mathrm{Hb}$ chain synthesis. Am J Hematol 1979;6:91-106.

${ }^{3}$ Embury SH, Dozy AM, Miller J, et al. Concurrent sickle cell anemia and thalassemia. $N$ Engl $J$ Med 1982;306:270-4.

4 Higgs D, Aldridge BE, Lamb J, et al. The interaction of alphathalassaemia and sickle cell disease. $N$ Engl J Med 1982;306:1441-6.

${ }^{5}$ Serjeant GR, Serjeant BE. A comparison of erythrocyte characteristics in sickle cell syndromes in Jamaica. $\mathrm{Br} J$ Hae:natol 1972;23:205-16.

- Hussain AM, Davis LR, Lanlicht M, Hoffbrand AV. Value of serum ferritin estimation in sickle cell anaemia. Arch Dis Child 1978;53:319-21.

' Peterson CM, Graziano JH, de Cinitis A, et al. Iron metabolism, sickle cell disease, and response to cyanate. Blood 1975;46:583-90.

- O'Brien RT. Iron burden in sickle cell anaemia. $J$ Pediatr 1978;92:579-82.

- Rao NJ, Sur AM. Iron deficiency in sickle cell disease. Acta Paediatr Scand 1980;69:337-40.

${ }^{10}$ Vichinsky E, Kleman K, Embury S, Lubin B. The diagnosis of iron deficiency in sickle cell disease. Blood 1981;58:963-8.

" Betke K, Marti HR, Schlicht I. Estimation of small percentages of foetal haemoglobin. Nature 1959;184:1877-8.

12 Young DS, Hicks JM. Method for automatic determination of serum iron. J Clin Pathol 1965;18:98-102.

${ }^{13}$ Addison GM, Beamish MR, Hales CM, Hodkins M, Jacobs A, Llewellin R. An immunoradiometric assay for ferritin in the serum of normal subjects and patients with iron deficiency and overload. J Clin Pathol 1972;25:326-9.

${ }^{14}$ Clegg JB, Naughton MA, Weatherall DJ. Abnormal human haemoglobins; separation of the $\alpha$ and $\beta$ chains by chromatography, and the determination of two new variants, $\mathrm{Hb}$ Chesapeak and Hb J (Bangkok). J Mol Biol 1966;19:91-108.

15 Washington R, Boggs DR. Urinary iron in patients with sickle cell anaemia. J Lab Clin Med 1975;86:17-23.

${ }^{16}$ Walford DM, Deacon R. Globin chain biosynthesis in iron deficiency. Br J Haematol 1980;44:201-9.

Requests for reprints to: Dr Milica Brozović, Consultant Haematologist, Central Middlesex Hospital, Acton Lane, London NW10 7NS, England. 